\title{
Effect of somatostatin on the mass accumulation of inositol-1,4,5- trisphosphate in rat hypothalamus, striatum, frontoparietal cortex and hippocampus
}

\author{
G. Muñoz-Acedo, R.M. Izquierdo-Claros, J.A. Sánchez-Alonso, N. del Hoyo, \\ M.A. Pérez-Albarsanz, E. Arilla* \\ Unidad de Neuroendocrinología Molecular, Departamento de Bioquímica y Biología, Molecular, Facultad de Medicina, \\ Universidad de Alcalá, E-2887I, Alcalá de Henares, Madrid, Spain
}

Received 19 May 1995; revised version received 2 August 1995; accepted 2 August 1995

\begin{abstract}
Somatostatin-14 (SS) significantly increased inositol-1,4,5-trisphosphate $\left(\mathrm{IP}_{3}\right)$ accumulation in rat hypothalamic, striatal, frontoparietal cortical and hippocarnpal slices. However, this stimulation of $\mathrm{IP}_{3}$ accumulation by $\mathrm{SS}$ was highest in the frontoparietal cortex and hippocampus. The effect was already significant with $0.01 \mu \mathrm{M}$ in the frontoparietal cortex $(P<0.05)$ and hippocampus $(P<0.05)$ and the maximal accumulation was evident with $0.1 \mu \mathrm{M} \mathrm{SS}$, in all areas studied. A concentration of $1 \mu \mathrm{M}$ SS, lacked this effect in hypothalamus and striatum. SS rapidly increased $\mathrm{IP}_{3}$ accumulation in all brain areas studied. This effect was maximal at $15 \mathrm{~s}$ of incubation and decreased subsequently. At $60 \mathrm{~s}$ incubation, levels were still elevated in frontoparietal cortex and hippocampus but had returned to basal values in hypothalamus and striatum. Somatostatin-28 (SS-28) and the SS analogues, D-Trp ${ }^{8}$-D-Cys ${ }^{14}$ and SMS 201-995, also significantly stimulated $\mathrm{IP}_{3}$ accumulation although the effect of SMS 201-995 was greater than that of SS in the striatum in comparison with controls $(P<0.001$ and $P<0.01$, respectively). These results suggest that $S S$ action at the hypothalamus, striatum, frontoparietal cortex and hippocampus is mediated at least in part by the accumulation of $\mathrm{IP}_{3}$, which may initiate intracellular processes responsible for some biological SS effects.
\end{abstract}

Keywords: Somatostatin; Inositol-1,4,5-trisphosphate; Brain; Rat

The tetradecapeptide somatostatin-14 (SS), is widely distributed through the central nervous system (CNS) [22]. Its highest concentration is found in the hypothalamus [22]. SS acts in the CNS as a neurotransmitter or neuromodulator, in both an excitatory and inhibitory manner [7]. The actions of SS are mediated through its specific receptors (SSTRs) $[6,7,19,26]$. Up to now, five subtypes of SSTRs have been cloned (SSTR1 to SSTR5) $[9,10]$. SSTRs have been reported to be coupled to several intracellular effector systems, including adenylate cyclase [23] and ion channels [30,31]. Recent studies suggest that inositol-1,4,5-trisphosphate $\left(\mathrm{IP}_{3}\right)$ is also involved in the mechanism of action of SS $[1,12,13,15,16,18,25]$. The SSTRs in hypothalamus and striatum, two specific areas for SS action $[7,8,28]$, are coupled to phospholipase C

\footnotetext{
* Corresponding author, Fax: +3418854585 .
}

(PLC) [1]. The facts that SS stimulates phosphoinositide (PI) hydrolysis in the hippocampus $[12,25]$ and that the hippocampus and striatum are closely associated structures [27], suggest that SS can also modify $\mathrm{IP}_{3}$ accumulation in this brain area. However, to date the effect of SS on accumulation of $\mathrm{IP}_{3}$ in the hypothalamus and striatum is unknown. The present study was undertaken to determine the effect of SS on accumulation of $\mathrm{IP}_{3}$ in rat hypothalamic and striatal slices. In order to compare with other brain areas, the frontoparietal cortex and hippocampus were also studied.

SS and somatostatin-28 (SS-28) were purchased from Universal Biologicals Ltd. (Cambridge, UK); SMS 201995 from Sandoz (Basel, Switzerland); $\mathrm{IP}_{3}$ and inositol1,2,3,4,5,6-hexaphosphate $\left(\mathrm{IP}_{6}\right)$ from Calbiochem (San Diego, CA, USA); $\left[{ }^{3} \mathrm{H}\right] \mathrm{IP}_{3}$ from Du Pont (Boston, MA, USA); and DL-dithiothreitol (DTT) from Sigma (St Louis, MO, USA). 


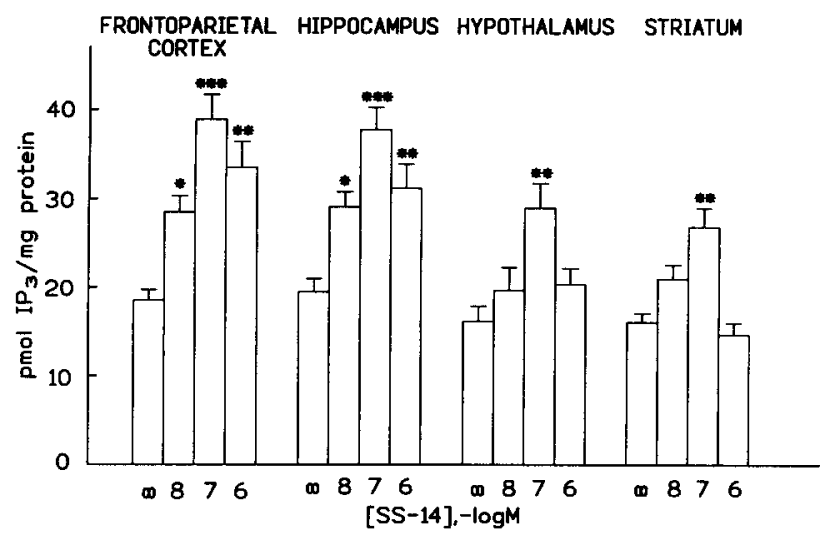

Fig. 1. Concentration-dependent effect of SS-14 on the accumulation of $\mathrm{IP}_{3}$ in frontoparietal cortex, hippocampal, hypothalamic and striatal slices. Brain slices were incubated for $15 \mathrm{~s}$ at $37^{\circ} \mathrm{C}$ with the different concentrations of SS-14. Values are expressed as the mean $\pm S E M$ of five separate experiments. Statistical comparison versus control: $* P<0.05, * * P<0.01$ and $* * * P<0.001$

Cross-chopped brain slices $(350 \times 350 \mu \mathrm{m})$ were prepared from male Wistar rats $(230-250 \mathrm{~g})$ and preincubated for $45 \mathrm{~min}$ at $37^{\circ} \mathrm{C}$ in Krebs bicarbonate buffer $(118 \mathrm{mM} \mathrm{NaCl}, 4.7 \mathrm{mM} \mathrm{KCl}, 1.3 \mathrm{mM} \mathrm{CaCl}, 1.2 \mathrm{mM}$ $\mathrm{KH}_{2} \mathrm{PO}_{4}, 1.2 \mathrm{mM} \mathrm{MgSO}_{4}, 25 \mathrm{mM} \mathrm{NaHCO}, 11.7 \mathrm{mM}$ glucose, $\mathrm{pH}$ 7.4, saturated with $\mathrm{O}_{2} / \mathrm{CO}_{2}$ (95:5)) with buffer replacement and gassification every 15 min [4]. Slices were allowed to sediment and $50 \mu 1$ of packed slices were added to $220 \mu 1 \mathrm{Krebs}$ buffer; these samples were gassed regularly, capped and incubated. All additions of test substances were made in a volume of $30 \mu 1$. Incubations were terminated by addition of $300 \mu 115 \%$ trichloroacetic acid (TCA). Acidified samples were left on ice for $15 \mathrm{~min}$ and centrifuged for $5 \mathrm{~min}$ at $2000 \times \mathrm{g}$. The supernatants $(500 \mu \mathrm{l})$ were left for $15 \mathrm{~min}$ at room temperature and then TCA was removed by five successive washings with 2 vols. of water-saturated diethyl ether and the addition of $125 \mu 130 \mathrm{mM}$ EDTA and $30 \mu 16 \mathrm{mM}$ $\mathrm{NaHCO}_{3}$. The protein concentration was determined in the tissue pellets according to the method of Lowry et al. [14].

The specific binding of $\left[{ }^{3} \mathrm{H}\right] \mathrm{IP}_{3}$ to a particulate preparation of bovine adrenal cortex was used as a radioreceptor assay to determine the concentration of $\mathrm{IP}_{3}$ in these slices by the method described by Challis et al. [4]. Aliquots of the binding protein obtained previously [4] were dissolved in $0.05 \%$ sodium azide, $5 \mathrm{mM}$ EDTA, $5 \mathrm{mM}$ EGTA, $50 \mathrm{mM}$ TAPS (pH 8.6), at a protein concentration of $1.5 \mathrm{mg} / \mathrm{ml}$. Then $3.5 \times 10^{-2} \mu \mathrm{Ci}$ of $\left[{ }^{3} \mathrm{H}\right] \mathrm{IP}_{3}$ was added per $\mathrm{ml}$ of solution to prepare the receptor-tracer solution. Assays were performed in a final volume of $500 \mu \mathrm{l}$. Receptor-tracer solution $(400 \mu \mathrm{l})$ was added to $100 \mu \mathrm{l}$ of unknown samples or $100 \mu \mathrm{l}$ of standard samples containing $\mathrm{IP}_{3}(0.6-24 \mathrm{pmol}$ in $1 \mathrm{mM}$ EDTA, $1 \mathrm{mM}$ EGTA, pH 7.5) or $\mathrm{IP}_{6}(1 \% \mathrm{w} / \mathrm{v}$ in $20 \mathrm{mM}$ EDTA, $20 \mathrm{mM}$ EGTA, $0.05 \%$ sodium azide, $\mathrm{pH} 7.5$ ) to define non-specific binding. All tubes were incubated for $1 \mathrm{~h}$ at $4^{\circ} \mathrm{C}$. Separation of bound and free $\mathrm{IP}_{3}$ was achieved by centrifugation at $12000 \times \mathrm{g}$ for $10 \mathrm{~min}$. After aspiration of the supernatant, $50 \mu \mathrm{l}$ of $0.15 \mathrm{M} \mathrm{NaOH}$ was added to each tube and the pellet dissolved by shaking. The radioactivity was determined by liquid scintillation spectrometry. The $\mathrm{IP}_{3}$ content was determined by comparing the extent of the inhibition of $\left[{ }^{3} \mathrm{H}\right] \mathrm{IP}_{3}$ binding with a calibration curve obtained with known amounts of $\mathrm{IP}_{3}$. Non-specific binding was about $13 \%$ of the total binding.

Statistical comparisons of all the data were analyzed by ANOVA and the Newman-Keuls $t$-test. Means between groups were considered significantly different when the $P$ value was less than 0.05 . Each individual experiment was performed in duplicate.

SS significantly increased $\mathrm{IP}_{3}$ accumulation in all brain areas investigated and this increase was highest in the frontoparietal cortex and hippocampus (Fig. 1). The effect was already significant with $0.01 \mu \mathrm{M}$ in the frontoparietal cortex $(P<0.05)$ and hippocampus $(P<0.05)$ and the maximal accumulation was evident at $0.1 \mu \mathrm{M} \mathrm{SS}$, in all areas studied $(2.1,1.9,1.8$ and 1.7-fold increase over basal values in frontoparietal cortex, hippocampal, hypothalamic and striatal slices, respectively). A concentration of $1 \mu \mathrm{M}$ SS lacked this effect in striatum and hypothalamus. Since there are five SS receptor subtypes, SSTR1-5, in the CNS [10], and their number, affinity for SS [10] and ability to activate PLC [1] all vary, an explanation for this result could be that $\mathrm{IP}_{3}$ accumulation occurs with higher affinity receptors. Occupation of lower affinity receptors by SS might reduce accumulated $\mathrm{IP}_{3}$.

SS rapidly increased $\mathrm{IP}_{3}$ accumulation in all brain areas studied (Fig. 2). This effect was maximal at $15 \mathrm{~s}$ of incubation and decreased subsequently. After $60 \mathrm{~s}$ the levels in frontoparietal cortex and hippocampus were still elevated whereas those in hypothalamus and striatum returned to control values.

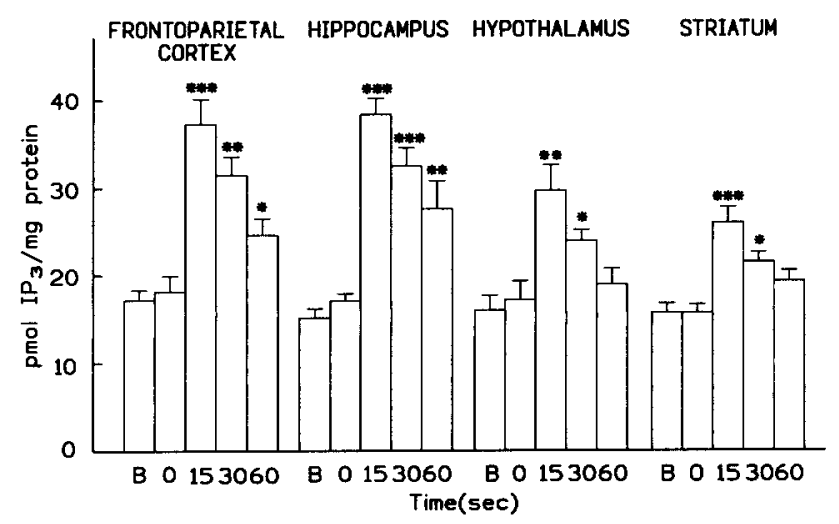

Fig. 2. Time-course effect of $10^{-7} \mathrm{M}$ of SS-14-induced $\mathrm{IP}_{3}$ accumulation in frontoparietal cortex, hippocampal, hypothalamic and striatal slices. Values are expressed as the mean \pm SEM of five separate experiments. Statistical comparison versus control: ${ }^{*} P<0.05,{ }^{* *} P<0.01$ and ${ }^{* * *} P<0.001$. B, basal. 


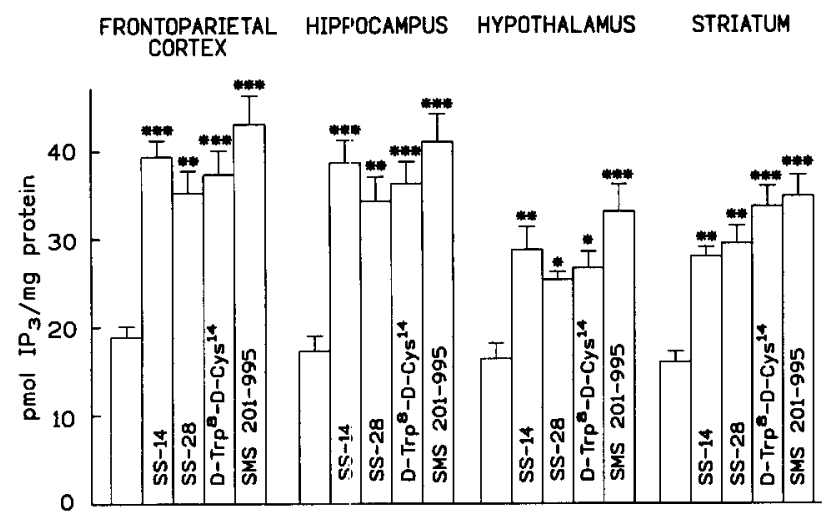

Fig. 3. Effect of various SS analogues on $\mathrm{IP}_{3}$ accumulation in frontoparietal cortex, hippocampal, hypothalamic and striatal slices. Brain slices were incubated for $15 \mathrm{~s}$ at $37^{\circ} \mathrm{C}$ with $10^{-7} \mathrm{M}$ of the different SS peptides. Values are expressed as the mean \pm SEM of five separate experiments. Empty bars correspond to the basal values. Statistical comparison versus control: $* F<0.05, * * P<0.01$ and $* * * P<0.001$.

The effects of SS-28 and two SS analogues, D-Trp ${ }^{8}$-DCys ${ }^{14}$ and SMS 201-995, on $\mathrm{IP}_{3}$ accumulation were also studied. All peptides significantly stimulated $\mathrm{IP}_{3}$ accumulation although the effect of SMS 201-995 was higher than that of SS in the striatum in comparison with controls $(P<0.001$ and $P<0.01$ respectively) (Fig. 3$)$. In the hypothalamus the effect: of SMS 201-995 also seems to be greater than SS but this difference is not statistically significant (Fig. 3).

A similar effect of $\mathrm{SS}_{\mathrm{S}}$ on $\mathrm{IP}_{3}$ accumulation has already been observed in cerebral cortex [12], hippocampus $[12,15]$, pituitary gland [12], bovine adrenal gland [18], SSTR1-expressing Chirese hamster ovary (CHO) cells [11] and COS-7 cells transfected with human SS receptors (hSSTR) [29]. The regional pattern of SS response may be accounted for by the regional distribution of SSTRs $[6,26]$ or may be due to a regional difference in the efficiency of the coupling mechanism, perhaps via nucleotide-regulated protein [5] between the SSTRs subtypes and PLC.

The effect of SS on $\mathrm{IP}_{3}$ accumulation seems to be a direct consequence of SSTR occupancy. Recently, it has been reported that cloned hSSTR subtypes 1-5 activate PLC and mobilize $\mathrm{Ca}^{2+}$ in transfected COS-7 cells [1]. Activation of PLC by SS is in the order hSSTR5 $>$ hSSTR2 $>$ hSSTR3 $>$ hSSTR4 $>$ hSSTR1 [1]. The hypothalamus shows a very high level of SSTR5 expression and moderate levels of other subtypes of SSTR coupled to PLC [10]. The fact that SS does not increase further $\mathrm{IP}_{3}$ accumulation in the hypothalamus could be due to the high endogenous SS content [22]. Expression of these SSTR subtypes in striatum and other brain areas has been reported [10]. However, since cyclic AMP (cAMP) has been shown to inhibit PI breakdown in a number of cell systems [20] and SS decreases cAMP levels [23], it is possible that the $\mathrm{IP}_{3}$ accumulation induced by SS could also occur at the cAMP level.
The SS concentration eliciting the maximal $\mathrm{IP}_{3}$ accumulation was about two orders of magnitude higher than the corresponding binding affinities obtained in previous studies $[6,19,26]$. This discrepancy can be explained by the different experimental conditions used in each type of experiment. Our previous binding studies were obtained at equilibrium after an incubation of $60 \mathrm{~min}$ at $30^{\circ} \mathrm{C}$ [19]. In contrast, $\mathrm{IP}_{3}$ accumulation is a transient process that must be measured $15 \mathrm{~s}$ after exposing brain slices to SS. Therefore, this very short time may not be sufficient to reach binding equilibrium. The fast and transitory character of $\mathrm{IP}_{3}$ formation is compatible with a function of this molecule as a second messenger.

Whether or not the SS-evoked $\mathrm{IP}_{3}$ accumulation in the slices is derived from neuronal cells is unknown. In this regard, SS is known to potentiate de- $\alpha_{1}$-adrenergic activation of PLC in striatal astrocytes [16]. Therefore, the possibility that the SS-evoked increase in $\mathrm{IP}_{3}$. accumulation in the studied brain slices could be derived from glial cells cannot be excluded. SS directly activates serotonergic and dopaminergic nerve terminals to release serotonin [28] and dopamine [8], respectively, and this is additional support for the notion that SS acts, at least in part, on $\mathrm{IP}_{3}$ signaling in the hypothalamic, striatal, hippocampal and cortical neurons.

The robust $\mathrm{IP}_{3}$ response produced by SMS 201-995 may be due to the activation of SSTR subtypes that have very high affinity (SSTR2, SSTR5) or some affinity (SSTR3) for this SS analogue [10] and that powerfully activate the PLC-Ca ${ }^{2+}$ system [1].

The accumulation of $\mathrm{IP}_{3}$, which is known to release calcium from internal stores [2] may provide a mechanism for the SSTRs-mediated cellular effects of SS. A few studies have reported that SS activates PLC followed by $\mathrm{Ca}^{2+}$ mobilization in native SS receptor-expressing cells such as striatal astrocytes [16] and NG 108-15 neuroblastoma $\times$ glioma hybrid cells (NG 108-15 cells) [21]. A requirement for $\mathrm{Ca}^{2+}$-dependent phospholipase $\mathrm{A}_{2}$ activation has also been postulated in SS actions in hippocampal cells [24]. SS facilitates neurotransmitter release $[8,28]$, long-term potentiation [17] and neurite growth [3]. All these responses may be secondary to receptor-mediated PI hydrolysis and subsequent mobilization of intracellular $\mathrm{Ca}^{2+}[2]$.

The authors thank Santiago Sanz and Angela Martín for their technical assistance and Carol F. Warren from the Alcalá de Henares University Institute of Education Sciences and Lilian Puebla from Alcalá de Henares University for their linguistic assistance. This work was supported by a Grant (PB94-0339) from the Dirección General de Investigación Científica y Técnica of Spain.

[1] Akbar, M., Okajima, F., Tomura, H., Majid, M.A., Yamada, Y., Seino, S. and Kondo, Y., Phospholipase $\mathrm{C}$ activation and $\mathrm{Ca}^{2+}$ mobilization by cloned human somatostatin receptor subtypes 1 5, in transfected COS-7 cells, FEBS Lett., 348 (1994) 192-196. 
[2] Berridge, M.J., Inositol trisphosphate and calcium signalling, Nature, 361 (1993) 315-325.

[3] Bulloch, A.G.M., Somatostatin enhances neurite outgrowth and electrical coupling of regenerating neurons in Helisoma, Brain Res., 412 (1987) 6-17.

[4] Challiss, R.A.J., Batty, I.H. and Nahorski, S.R., Mass measurements of inositol $(1,4,5)$ trisphosphate in rat cerebral cortex slices using a radioreceptor assay: Effects of neurotransmitters and depolarization, Biochem. Biophys. Res. Commun., 157 (1988) 684691

[5] Cockcroft, S., Polyphosphoinositide phosphodiesterase: regulation by a novel guanine nucleotide binding protein $\mathrm{Gp}$., Trends Biochem. Sci., 12 (1987) 75-78.

[6] Czernik, A.J. and Petrack, B., Somatostatin receptor binding in rat cerebral cortex, characterization using a non reducible somatostatin analog. J. Biol. Chem., 256 (1983) 5525-5530.

[7] Epelbaum, J., Somatostatin in the central nervous system: physiology and pathological modifications, Prog. Neurobiol., 27 (1986) 63-100.

[8] García-Sevilla, J.A., Magnusson, T. and Carlsson, A., Effect of intracerebroventricularly administered somatostatin on brain monoamine turnover, Brain Res, 155 (1978) 159-164.

[9] Hoyer, D., Bell, G.I., Berelowitz, M., Epelbaum, J., Feniuk, W., Humphrey, P.P.A., O'Carrol, A.-M., Patel, Y.C., Schonbrunn, A. Taylor, J.E. and Reisine, T., Classification and nomenclature of somatostatin receptors. Trends Pharmacol. Sci., 16 (1995) 8688.

[10] Hoyer, D., Lübbert, H. and Bruns, C., Molecular pharmacology of somatostatin receptors, Naunyn-Schmiedeberg's Arch. Pharmacol., 350 (1994) $441-453$.

[11] Kubota, A., Yamada, Y., Kagimoto, S., Yasuda, K., Someya, Y., Ihara, Y., Okamoto, Y., Kozasa, T., Seino, S. and Seino, Y., Multiple effector coupling of somatostatin receptor subtype SSTRI, Biochem. Biophys. Res. Commun., 204 (1994) 176-186.

[12] Lachowicz, A., Pawlikowski, M. and Ochedalski, T., Somatostatin-14 increases the inositol-1,4,5-trisphosphate content in various areas of the brain, Biochem. Biophys. Res. Commun., 203 (1994) 379-384.

[13] Lachowicz, A., Stepien, H., Kunert-Radek, J. and Pawlikowski, M., Effects of somatostatin on inositol-1,4,5-trisphosphate content in mouse spleen lymphocytes, Comp. Biochem. Physiol., 101A (1992) 661-664.

[14] Lowry, O.H., Rosebrough, N.J., Farr, A.L. and Randall, R.J., Protein measurement with the Folin phenol reagent, J. Biol. Chem., 193 (1951) 265-275.

[15] Malm, D., Giaever, A., Vonen, B., Burhol, P.G. and Florholmen, J., Somatostatin inhibition of phospholipase $C$ activity in isolated rat pancreatic islets, Acta Physiol. Scand., 143 (1991) 413419 .

[16] Marin, P., Delumeau, J.C., Tence, M., Cordier, J., Glowinski, J. and Premont, J., Somatostatin potentiates the $\alpha_{1}$-adrenergic activation of phospholipase $C$ in striatal astrocytes through a mecha- nism involving arachidonic acid and glutamate, Proc. Natl. Acad Sci. USA, 88 (1991) 9016-9020.

[17] Matsuoka, N., Kancko, S. and Satoh, M., Somatostatin augments long-term potentiation of the mossy fiber-CA3 system in guinea pig hippocampal slices, Brain Res, 553 (1991) 188-194.

[18] Moeller, I., Bunn, S.J. and Marley, P.D., Actions of somatostatin on perfused bovine adrenal glands and cultured bovine adrenal medullary cells, Brain Res., 484 (1989) 192-202.

[19] Muñoz-Acedo, G., López-Sañudo, S. and Arilla, E., Effect of serotonin axon injury on the somatostatinergic system in rat frontoparietal cortex, Life Sci., 52 (1993) 803-809.

[20] Nishizuka, Y., Turnover of inositol phospholipids and signal transduction, Science, 225 (1984) 1365-1370.

[21] Okajima, F. and Kondo, Y., Synergism in cytosolic $\mathrm{Ca}^{2+}$ mobilization between bradykinin and agonists for pertussis toxinsensitive G-protein-coupled receptors in NG 108-15 cells, FEBS Lett., 30I (1992) 223-226

[22] Patel, J.C. and Reichlin, S., Somatostatin in hypothalamus, extrahypothalamic brain and peripheral tissues of the rat, Endocrinology, 102 (1978) 523-531.

[23] Schettini, G., Florio, T., Meucci, O., Landolfi, E., Grimaldi, M., Ventra, C. and Marino, A., Somatostatin inhibition of adenylate cyclase activity in different brain areas, Brain Res., 492 (1989) $65-71$.

[24] Schweitzer, P., Madamba, S. and Siggins, G.R., Arachidonic acid metabolites as mediators of somatostatin-induced increase of neuronal M-current, Nature, 346 (1990) 464-467.

[25] Shaffer, L.M. and Dokas, L.A., Carbachol and [D-Trp ${ }^{8}$ somatostatin interact to regulate hippocampal phosphoinositide metabolism, Neurosci. Res. Commun., 8 (1991) 147-152.

[26] Srikant, C.B. and Patel, Y.C., Somatostatin receptors: identification and characterization in rat brain membranes, Proc. Natl Acad. Sci. USA, 78 (1981) 3930-3934.

[27] Swanson, L.W., Köhler, C. and Björklund, A., The limbic region. I: The septohippocampal system. In A. Björklund, T. Hokfelt and L.W. Swanson (Eds.), Handbook of Chemical Neuroanatomy, Vol. 5, Elsevier, Amsterdam, 1987, pp. 125-277.

[28] Tanaka, S. and Tsujimoto, A., Somatostatin facilitates the serotonin release from rat cerebral cortex, hippocampus and hypothalamus slices, Brain Res, 208 (1981) 219-222.

[29] Tomura, H., Okajima, F., Akbar, M., Majid, M.A., Sho, K. and Kondo, Y., Transfected human somatostatin receptor type 2, SSTR2, not only inhibits adenylate cyclase but also stimulates phospholipase $\mathrm{C}$ and $\mathrm{Ca}^{2+}$ mobilization, Biochem. Biophys. Res. Commun., 200 (1994) 986-992.

[30] Wang, H.L., Reisine, T. and Dichter, M., Somatostatin-14 and somatostatin-28 inhibit calcium currents in rat neocortical neurons, Neuroscience, 38 (1990) 335-342.

[3I] Wang, H.L., Bogen, C., Reisine, T. and Dichter, M., Somatostatin- 14 and somatostatin-28 induce opposite effects on potassium currents in rat neocortical neurons, Proc. Natl. Acad. Sci. USA, 86 (1989) 9616-9620 